\title{
Relation Between Relative Efficiencies and Brand Values of Global Turkish Banks Trading on Istanbul Stock Exchange*
}

\author{
Aslan Gülcü \\ Ataturk University, Erzurum, Turkey
}

\begin{abstract}
The global competition in banking sector, global capital flows, and proliferation of financial markets have been forcing banks to utilize their resources in an efficient way and use various methods to determine and increase their performances against the competitors. Within this context, the relative efficiency measurement and statistical (parametric) efficiency measurements that employ (non-parametric) mathematical programming based on Data Envelopment Analysis (DEA) method are such instruments and they are used to determine brand value and financial performance that are pivotal factors in company mergers, acquisitions, and joint venture activities. This study works with Turkish banks whose brand values have been calculated by Brand Finance and whose brand values have been listed in Global Banking 500 for the years between 2010 and 2012. Firstly, using the banks' data published by Public Disclosure Platform (PDP/KAP), a non-parametric model with three inputs and four outputs has been developed. Relative and super efficiencies of the banks have been measured by mathematical programming based DEA and the efficiency scores that come out of this analysis have been ranked, resulting in an "efficiency ranking of the banks". Following this, the efficiency ranking of these banks has been compared with brand value ranking of Brand Finance and their similarity/correspondence has been assessed.
\end{abstract}

Keywords: Data Envelopment Analysis (DEA), banking, brand value, brand valuation, Istanbul stock exchange

\section{Introduction}

The banking has almost become entirely internationally regulated sector. In order for the banks to gain competitive advantage due to developments in the world and to maintain sustainability, they must achieve higher success rates than their competitors and continue with this success track record. Along with ability of companies to manage their tangible assets and resources, this success also depends on their ability to become superior in intangible assets and maintain this superiority. Therefore, one of the intangibles heavily emphasized in intangible assets of enterprises in the recent years is the brand and brand valuation. The fact that importance of brand as a value creation element has become more evident in recent years has mobilized world's prominent institutions providing advisory and consulting services.

Brand valuation techniques played pivotal roles in 1980s in company acquisitions, takeovers, and joint ventures. Many companies paid much higher prices than the balance sheet value to the target companies in

\footnotetext{
* Acknowledgments: The author gratefully thanks lecturer Hatice Cenger, Muğla S.K. University, Türkiye.

Aslan Gülcü, Ph.D., professor at Ataturk University, Educational Faculty Department of Computer Educaiton and Instructional Technologies, Erzurum, Turkey.

Correspondence concerning this article should be addressed to Aslan Gülcü, Ataturk University Campus, School Street, Faculty of Education Building, No. 205, 25240 Erzurum, Turkey. E-mail: agulcu@atauni.edu.tr.
} 
merger and acquisition deals and they announced that the high costs were attributable particularly to brand values (Marangoz, 2007). Therefore, when the value of the brand or other non-tangible assets exceed the value of other tangible assets (like land, buildings, machinery, and equipments etc.) owned by the company, the value of the brand must be known in order to determine value of the institution in question (Ilguner, 2009).

The buyer, investor, and the bank of the companies having a branded product use the brand valuation as security in regards to acquisition price's correspondence to value of acquired non-tangible assets (Ilguner, 2009).

On one hand, this situation shows the importance of brand valuation, on the other hand, world's most powerful brands' ranking compiled with respect to their dollar values is also important as it shows that brands do contribute to the development of an enterprise in a big way. In addition to that, due to the fact that companies with high brand value perform significantly better in stock markets, determining the brand value in a most accurate and realistic way is also important for validity of this relation (Ozguven, 2010).

In this study, the relative efficiencies of the banks, values of which have been calculated by world's leading brand valuation institution (Brand Finance) by their proprietary method, which are given a place in Global Banking 500 list with respect to their brand value ranking, and which are trading in Istanbul stock exchange, have been measured by non-parametric Data Envelopment Analysis (DEA) method. The resulting relative efficiency ranking has been compared with ranking of banks' brand values.

Brand Finance's method comprises of basically two stages. In the first stage, company's revenues and costs associated with the brand are separated, future cash flow projections are constructed, and net present value of these future cash flows are discounted to find the "financial value". In the second stage, however, by conducting market research studies requiring one on one contact with the consumers, proportional contribution of the brand out of brand related activities is determined (Çilingir, 2009).

DEA method, however, is a mathematical programming based method which is used to measure relative efficiency of organizational units that perform similar activities and have multiple inputs/outputs. Particularly in the instances where more than one input or output cannot be converted into set of weighted input or output, the DEA is considered as an effective approach (Ulucan, 2002).

This study comprises of two sections as theory and application. In the first section, brand valuation methods and DEA are explained within theoretical context. In the application section of the study, by using financial data from Public Disclosure Platform (KAP) pertaining to banks that were ranked in Global Banking 500 lists of 2010-2012, their efficiencies have been measured by using DEA. Resulting efficiency and super efficiency ranking have been compared with brand value ranking of Brand Finance.

\section{Theory and Background}

\section{Brand Valuation Methods}

In addition to providing various advantages to the enterprise, a strong brand is also one of the most important assets that help the enterprise carry on in stiff competitive environments (Tek \& Ozgul, 2005).

If the brand achieves success in the market, then it becomes effective in increasing the positive difference between company's book value and market value. Therefore, when the companies become subject to an acquisition process, they are sold at higher prices than their book values because of their high brand values (Firat \& Badem, 2008).

The brand valuation, which has particularly become an important management instrument in the past decade, is used because of such reasons as increased importance of value based marketing, mergers, and 
acquisitions planning and determining non-tangible assets in company balance sheets.

As a result of recognition of brand as a value creating factor, the leading companies of the world started to understand and take brands' impact on their activities more seriously (Ilguner, 2009).

Knowing the brand value is also important for capital markets and other finance circles. If the brand value increases, then the shareholder's value increases, as well. Likewise, for the bankers, the brand value is a major credibility indicator. It can also be used as an important support element in Initial Public Offerings (IPOs). For these reasons, determining/measuring the brand value will allow the followings (Ilguner, 2009):

- understanding exactly the value created through brand and marketing;

- making the fundamental strategic decisions by analyzing the financial results;

- enhancing the value of activities and the brand by allocating the scarce resources in a right way.

Because brand has an important place in the field of marketing and it is a focus of interest for finance community due to the need for determining monetary value of intangible assets (Celik, 2013), several brand valuation methods have been developed from both marketing and finance perspectives, however, no commonly agreed upon method has been developed, yet. The methods that are being used now are based on many subjective assumptions and they can give very different results from one another (Marangoz, 2007).

With respect to their emergence over time, brand valuation methods can be ordered as: financial methods, behavioral methods, and mixed Methods (Yilmaz \& Guzel, 2012).

\section{Financial Methods}

Financial methods include the activities toward determining monetary value of the brands (Celik, 2013). Financial methods concentrate more on numerical values like price premiums and license fees and they ignore customer preferences and perspectives (Marangoz, 2007). These approaches are criticized on the grounds that they cannot grasp all the elements making up the brand power and they do not take customer behaviors and trends into consideration. The monetary methods do not provide a clear methodology to express the elements making up the brand value in monetary terms. Financial methods calculate the brand value swiftly by using readily available company financial data, however, they do not take into consideration the effects of customer preferences and market conditions, which have an effect on brand value (Kaya, 2005). Financial methods can be itemized as follows (Yilmaz \& Guzel, 2012):

- cost based brand valuation;

- market value based brand valuation;

- valuation based on capital markets;

- relief from royalty method;

- price premium method;

- other methods taking brand's excess returns into consideration;

- valuations based on financial ratios.

\section{Behavior Based Methods}

Behavior based methods bring brand's psychological effects into light and they use processes and data to measure brand power (Celik, 2013). Therefore, these methods are the models that take consumer behavior and preferences into consideration (Firat \& Badem, 2008). In some sources, the behavior based models are referred as "research based approaches". Instead of coming up with a brand value, these models appraise the behaviors and trends that have an effect on economic performance of the brand. All of these methods attempt to explain, 
interpret, and measure customer perceptions. In such models, there is usually no clear connection between the marketing indicators the company adopts and its financial success; therefore, one can argue that a company may have strong market indicators, yet this may not be interpreted as it has strong financial indicators in creating value (Kaya, 2005). Among these models, the most well-known models are the ones in the research of Celik (2013).

In these models, the concept of brand value and its explanatory factors are based on customer perceptions and behaviors. While customer perceptions are brand recognition, brand association, brand image, and perceived quality such factors as brand loyalty and accepting to pay higher price are related to consumer behavior (Aydin \& Uluengin, 2011).

\section{Mixed Methods}

These methods are made up of combination of financial models and behavior based models. After the enterprises started to have valuation services for their brands, many companies like Interbrand, Financial World, and Brand Finance started to provide this service by developing their own proprietary methods (Yilmaz \& Guzel, 2012). These methods are also the methods that were developed to benefit from strong aspects of both approaches. These methods value the brand with respect to several indicators and determine brand's power and they associate valuation results with the risk of whether the brand will earn the future projected incomes or not (discount rate or a multiplier value). By doing so, they establish a link between financial calculations and behavioral models.

In addition to methods developed by academicians, after the companies started to get valuation services, many consulting firms started to provide these services and developed their own methodologies. Therefore, the most well-known mixed methods are the ones that were developed by consulting firms (Kaya, 2005).

\section{Brand Finance Method}

This method that was developed by Brand Finance Consulting Firm consists of two main stages (Ilguner, 2009): calculation of branded business value and calculation of commercial brand value.

Calculation of branded business value. Branded business valuation is a company valuation. It is used in financial and strategic decision making and it involves the following stages:

- segmentation: Classification is made with respect to geographic dispersion and customer and brand scopes;

- financial forecasts: Financial forecasts for the market are made and sector trends are tried to be determined.

- determining value creating factors: conduct brand value added analysis. It determines proportion of future income attributable to the brand (Celik, 2013);

- determining market risk: determine market risks. By using an adaptation version of CAPM-Capital Asset Pricing Method, the discount rate required to calculate net present value of future forecasted earnings is calculated (Kaya, 2005).

Calculation of commercial brand value. The commercial brand value involves trade name plus patents, software, intellectual property rights, as well as goodwill and it consists of two stages: royalty and revenue sharing.

Royalty and revenue sharing. Royalty method is based on the assumption that the company does not have brand related intellectual or industrial property rights and it gets license from another company for these rights (Bayiksel, 2007). In other words, if a company without a brand wants to use the brand of another company to 
increase its sales, it will need to pay a royalty for this. Royalty is a value that comes with brand ownership.

When a brand is valued with Brand Finance's method, a lower and an upper limits are determined from the data set of worldwide sale and acquisitions of branded actions and a royalty weight is determined (e.g., as a result of sale and acquisitions in the construction industry determining the lower limit as 1.3 and upper limit as 4.2). Following this step, the brand power is adapted to this range and royalty rate is determined. Next, together with past couple of years' data, the forecast sales revenue of couple of future years is calculated and royalty rate is adapted to sales revenue. In this way, by determining realized and future revenues, the future revenues are discounted to present day with a discount rate, which is a function of brand and country risk. The resulting net present value is the brand value (Ilguner, 2009)

\section{Non-parametric Method: DEA}

The DEA, which is based on Farrel's theoretical approach (1957) in determining performance efficiency, has been developed by Charnes, Cooper, and Rhodes (1978) and is a linear programming based approach (Ulucan, 2002).

In the first DEA application, Charnes and his colleagues measured the efficiency of state schools in the US in 1978. While the studies were under way, Farell's study titled The Measurement of Productivity Efficiency drew Cooper's attention and Charnes, Cooper, and Rhodes expanded the scope of the study and applied the DEA method with success. Later in 1981, details of this study were defined as CCR (Charnes-Cooper-Rhodes) method (Charnes et al., 1978).

DEA is a mathematical programming based efficiency measurement method which is used to measure relative efficiency of organizational units that have multiple inputs/outputs. Particularly in the instances where more than one input or output cannot be converted into set of weighted inputs or outputs, the DEA is considered as an effective approach (Ulucan, 2000). The most important characteristic of the method is that it can define inefficiency amount and its sources at each of the Decision Making Unit (DMU). With this characteristic, this method can give useful clues to managers regarding how much (or at what rate) an input decrease and /or output increase is needed at inefficient units. The most important novelty of this method is that in today's environment where multiple inputs are used to obtain multiple outputs, it does not require assumption of existence of predefined production function, as is the case with parametric methods and it can perform measurement based on mathematical programming. Another significant feature of the method is that inputs and outputs are independent from measurement units. Therefore, it allows to measure different dimensions of the enterprise simultaneously (Karsak \& Iscan, 2000).

In DEA technique, a null input or output value should not be defined (Kuosmanen, 2003). Departing from single input/output structure in classical efficiency analysis, the DEA uses multiple input/output and along with its rapid theoretical development it has followed a fast track in applications, as well. Thousands of applications have been made in public service institutions such as hospitals, post offices, banks, courts, pharmacies, transportation, police stations, and educational organizations. The DEA which was used to measure comparative efficiencies at non-profit service sector public institutions initially is commonly used now at for-profit manufacturing and service sectors, too to measure technical efficiency among the enterprises (Gülcü, 2001).

The models used in DEA technique change with respect to DEA model and direction of the model. There are two models to determine efficiency border. These can be analyzed in two groups as "input oriented" and "output oriented". Although input oriented and output oriented DEA models fundamentally look very similar to 
each other, the input-oriented DEA models search for "what should be the most suitable input combination to be used for producing a certain output combination in the most effective way", while the output-oriented DEA methods search for "with a certain input combination what is the maximum output combination that can be obtained" (Charnes et al., 1978).

These techniques are also used to determine to what extent the inefficient DMU should decrease the inputs for a given product level. In the output-oriented efficiency measurement techniques, however, the objective is to determine maximum output levels that could be produced with the given input levels or to determine to what extent the inefficient DMU should increase the outputs for a given input combination (Bakirci, 2006).

\section{Mathematical Structure of DEA}

The first DEA model is the rational form that was developed by Charnes et al. (1978) and known as CCR model.

Objective function::

$$
\operatorname{Max}\left\{\theta_{0}=\frac{\sum_{i} \mu_{i} y_{i 0}}{\sum_{j} v_{i} x_{j 0}}\right\}
$$

Constraints:

$$
\frac{\sum_{i} \mu_{i} y_{i k}}{\sum_{j} v_{i} x_{j k}} \leq 1, k=1,2,3, \ldots, n, \text { for all DMUs. }
$$

Positive constraint:

$$
\mu_{i} \geq 0 \text { and } v_{i} \geq 0
$$

This model is CCR - input oriented rational form.

Where $\theta_{0}$ : efficiency score of zeroth DMU; $n$ : number of analyzed DMUs; $i$ : number of outputs; $j$ : number of inputs; $y_{k}=\left\{y_{1 k}, y_{2 k}, \ldots, y_{i k}, \ldots, y_{I k}\right\}$, for $k t h$ DMU, the $k$ th DMU's output vector where ith output value is $y_{i k} ; x_{k}=\left\{x_{1 k}, x_{2 k}, \ldots, x_{i k}, \ldots, x_{I k}\right\}$, for $k$ th DMU, $k$ th DMU's input vector where $j$ th input value is $x_{i k} ; \mu$ and $v$ are product vectors over $y_{k}$ and $x_{k}$, respectively; $\mu_{i}$ and $v_{j}$ are ith output and $j$ th input weighting, respectively.

When $j$ DMU sets are given, the model determines optimal weighted input/output set what maximizes $e_{0}$ efficiency score for each zeroth DMU.

With the above mentioned directions, efficiency can be determined as follows:

(1) In an output-oriented model: If increase of any output is possible without any input increase or output decrease, then this DMU is not efficient;

(2) In an output oriented model: If any of the outputs decreases without any increase in any of the inputs and decrease in any of the outputs, then this DMU is not efficient.

In order for a DMU to be characterized, satisfaction of neither (i) nor (ii) is not necessary and sufficient condition. The meaning of having an efficiency score of less than 1 is that in a linear combination of other DMUs, by using smaller input vector, output vector is obtained.

Weighted average of decision maker's inputs becomes equal to 1. Besides, for each decision maker, having weighted average of outputs less than weighted average of inputs is another condition. According to this condition, for the DMU whose efficiency values are desired to be calculated, the weighted average of their outputs can be maximum 1. Thus, for an effective decision maker, the efficient value should be 1 and for an inefficient decision maker, this value should be less than 1 . 


\section{Methodology}

In this study, in order to obtain efficiency of analyzed banks, DEA method has been used. This method is a "frontier" technique which is used to assess relative efficiency of different sectors with multiple input/output characteristics.

Due to the characteristics of the data set to be used in the analysis, this model has been preferred to have the following features: convex structure, scale dependent fixed income, input-oriented, and radial model. The efficiency scores measured with this model have been tested with "convex structure, scale dependent fixed income, output oriented, and radial model". After this double sided (input/output oriented) analysis, it has turned out that last three years' scores for DMUs were equal (meaning 100\%). In order to alleviate pilling up of scores at 1 , or in other words in order to find the efficient DMUs, this time super efficiency scores for the past three years have been calculated as input/output oriented (convex, scale dependent fixed income, and radial model).

The mathematical structure of the model used in the study can be written as a linear programming equation as follows (assuming input oriented):

$$
\begin{gathered}
\operatorname{Max}_{u, v}=\sum_{k} u_{k} y_{k j_{0}} \\
\sum_{i} v_{i} x_{i_{k} j_{0}}=1 \\
\sum_{k} u_{k} \cdot y_{k_{j}} \leq \sum_{i} v_{i} \cdot x_{i_{k_{j}}} \\
u_{k}, v_{i} \geq 0 .
\end{gathered}
$$

Equation (3) is the objective function of the model; equation (4) indicates that sum of weights of the inputs should be one; the inequality with equation (5) determines the direction of the orientation (being input/output oriented); and equation (6) guarantees that weights should be positive or equal to 0 . This model is called scale dependent fixed income Constant Return to Scale (CRS) model.

These scores that were found out as a result of efficiency and super efficiency analyses have been ordered in themselves and attempt has been made to explain their relation with brand values. The data have been assessed with a model mentioned in the EMS (Efficiency Measurement System) which has been designed for academic users.

Input and output variables have been taken from balance sheets and income statements of DMU published at KAP. In this study, three input variables and four output variables have been used. Using these variable headings the period between 2010 and 2012 has been put into analysis (Table 1).

Table 1

Input/Output Values and Other Parameters Used in the Research (Input Output Values Are Denominated in Turkish Lira)

\begin{tabular}{lclllllllll}
\hline & \multicolumn{4}{c}{ Inputs } & \multicolumn{6}{c}{ Outputs } \\
\hline Decision units & Years & $\begin{array}{l}\text { Interest } \\
\text { expenses }\end{array}$ & $\begin{array}{l}\text { Other } \\
\text { operative } \\
\text { expenses }\end{array}$ & Deposits & \multicolumn{2}{l}{$\begin{array}{l}\text { Loans } \\
\text { receivables }\end{array}$} & $\begin{array}{l}\text { and Interest } \\
\text { revenues }\end{array}$ & $\begin{array}{l}\text { Other } \\
\text { operative } \\
\text { revenues }\end{array}$ & Net profit values \\
\hline \multirow{3}{*}{ ISBANK } & 2010 & $5,264,964$ & $3,203,123$ & $88,260,157$ & $69,077,804$ & $9,797,839$ & $1,569,284$ & $2,982,210$ & $91(1)$ \\
& 2011 & $6,336,584$ & $3,481,199$ & $64,989,794$ & $71,841,167$ & $10,898,384$ & $1,311,114$ & $2,667,487$ & $75(1)$ \\
& 2012 & $6,291,675$ & $2,968,464$ & $90,688,288$ & $92,360,249$ & $11,649,475$ & 415,363 & $3,004,948$ & $98(2)$ \\
\hline
\end{tabular}


Table 1 to be continued

\begin{tabular}{|c|c|c|c|c|c|c|c|c|c|}
\hline \multirow[b]{2}{*}{ Decision units } & \multirow[b]{2}{*}{ Years } & \multicolumn{3}{|c|}{ Inputs } & \multicolumn{4}{|c|}{ Outputs } & \multirow[b]{2}{*}{$\begin{array}{l}\text { Brand } \\
\text { values }\end{array}$} \\
\hline & & $\begin{array}{l}\text { Interest } \\
\text { expenses }\end{array}$ & $\begin{array}{l}\text { Other } \\
\text { operative } \\
\text { expenses }\end{array}$ & Deposits & $\begin{array}{l}\text { Loans an } \\
\text { receivables }\end{array}$ & $\begin{array}{l}\mathrm{d} \text { Interest } \\
\text { revenues }\end{array}$ & $\begin{array}{l}\text { Other } \\
\text { operative } \\
\text { revenues }\end{array}$ & Net profit & \\
\hline \multirow{3}{*}{ AKBANK } & 2010 & $4,563,572$ & $2,483,227$ & $71,708,335$ & $57,737,967$ & $8,994,490$ & 902,212 & $2,856,529$ & $115(2)$ \\
\hline & 2011 & $5,321,916$ & 2514758 & $50,997,029$ & $58,890,183$ & $9,473,645$ & 704,835 & $2,535,125$ & $94(2)$ \\
\hline & 2012 & $7,462,498$ & $4,484,306$ & $105,383,434$ & $107,142,154$ & $13,390,415$ & $1,172,144$ & $3,310,307$ & $96(1)$ \\
\hline \multirow{3}{*}{$\begin{array}{l}\text { YAPI KREDI } \\
\text { BANK }\end{array}$} & 2010 & $2,622,197$ & $2,488,515$ & $52,724,532$ & $52,615,160$ & $5,821,799$ & $1,206,858$ & $2,060,290$ & $116(3)$ \\
\hline & 2011 & $3,845,460$ & $2,690,486$ & $41,440,810$ & $54,892,258$ & $7,155,567$ & 811,393 & $1,857,486$ & $117(4)$ \\
\hline & 2012 & $6,951,539$ & $3,540,901$ & $87,482,419$ & $91,824,492$ & $12,670,471$ & 298,616 & $3,070,325$ & $123(4)$ \\
\hline \multirow{3}{*}{$\begin{array}{l}\text { GARANTI } \\
\text { BANK }\end{array}$} & 2010 & $4,745,136$ & $3,040,830$ & $72,658,419$ & $64,827,310$ & $9,499,876$ & 637,989 & $3,127,964$ & $123(4)$ \\
\hline & 2011 & $5,794,581$ & $3,206,325$ & $49,998,883$ & $57,629,743$ & $10,483,529$ & 902,533 & $3,070,575$ & $95(3)$ \\
\hline & 2012 & $4,880,824$ & $2,992,925$ & $68,143,940$ & $74,769,316$ & $9,373,833$ & 338,192 & $1,913,472$ & $104(3)$ \\
\hline \multirow{3}{*}{ HALKBANK } & 2010 & $3,159,601$ & $1,495,270$ & $54,782,014$ & $44,269,487$ & $6,350,615$ & 574,420 & $1,843,291$ & $173(5)$ \\
\hline & 2011 & $3,805,417$ & $1,725,251$ & $54,150,513$ & $48,071,856$ & $7,278,660$ & 594,451 & $2,045,134$ & $156(6)$ \\
\hline & 2012 & $4,514,906$ & $2,097,656$ & $79,973,901$ & 65 & $8,990,983$ & 360,242 & 5,211 & $145(5)$ \\
\hline \multirow{3}{*}{ VAKIFBANK } & 2010 & $3,152,856$ & $1,689,813$ & $47,701,275$ & $44,861,019$ & $5,882,857$ & 601,030 & $1,157,140$ & $200(6)$ \\
\hline & 2011 & $3,607,349$ & $1,941,380$ & $49,566,239$ & $51,368,274$ & $6,501,067$ & 885,315 & $1,226,785$ & $149(5)$ \\
\hline & 2012 & $4,671,908$ & $2,261,175$ & $67,242,290$ & $68,133,039$ & $8,756,502$ & 624,680 & $1,460,080$ & $156(6)$ \\
\hline \multirow{3}{*}{$\begin{array}{l}\text { TURKISH } \\
\text { ECONOMY } \\
\text { BANK (TEB) }\end{array}$} & 2010 & 728,563 & 787,827 & $11,999,150$ & $11,753,255$ & $1,496,478$ & 474,860 & 300,301 & $280(7)$ \\
\hline & 2011 & $1,537,490$ & $1,379,141$ & $22,886,612$ & 52,425 & $2,912,492$ & 88,544 & 206,657 & 299(8) \\
\hline & 2012 & $2,699,274$ & $1,798,063$ & $32,921,506$ & $36,440,244$ & $5,576,401$ & 364,667 & 902,346 & - \\
\hline \multirow{3}{*}{ FINANSBANK } & 2010 & $1,538,137$ & $1,375,855$ & $24,430,677$ & $24,859,145$ & $3,792,561$ & 145,949 & 914,674 & $310(8)$ \\
\hline & 2011 & $2,309,462$ & $1,573,904$ & $22,718,197$ & $33,013,733$ & $4,534,312$ & 177,757 & 848,112 & $276(7)$ \\
\hline & 2012 & $1,952,917$ & $1,378,169$ & $26,696,342$ & $28,190,501$ & $4,095,468$ & 236,478 & 812,632 & $244(7)$ \\
\hline \multirow{3}{*}{ DENIZBANK } & 2010 & 1025457 & $1,072,156$ & $20,068,860$ & $21,945,780$ & $2,813,874$ & 408,146 & 616,291 & $380(9)$ \\
\hline & 2011 & 1389884 & $1,224,296$ & $17,897,127$ & $22,490,743$ & $3,071,080$ & 457,634 & 873,974 & $321(9)$ \\
\hline & 2012 & $6,291,675$ & $2,968,464$ & $90,688,288$ & $92,360,249$ & $11,649,475$ & 415,363 & $3,004,948$ & $286(8)$ \\
\hline \multirow{3}{*}{ BANKASYA } & 2010 & 613,392 & 530,287 & $7,813,463$ & $11,588,089$ & $1,206,903$ & 134,193 & 259,962 & $424(10)$ \\
\hline & 2011 & 646,931 & 563,367 & $12,397,042$ & $13,153,771$ & $1,278,154$ & 130,545 & 216,090 & $403(10)$ \\
\hline & 2012 & $7,462,498$ & $4,484,306$ & $105,383,434$ & $107,142,154$ & $13,390,415$ & $1,172,144$ & $3,310,307$ & - \\
\hline \multirow{3}{*}{ SEKERBANK } & 2010 & - & - & - & - & - & - & - & - \\
\hline & 2011 & 804,564 & 546,499 & $9,078,449$ & $8,510,111$ & $1,369,965$ & 120,641 & 118,044 & $410(11)$ \\
\hline & 2012 & - & - & - & - & - & - & - & - \\
\hline
\end{tabular}

\section{Findings}

In the Scale Dependent Fixed Income (SDFI) radial input oriented analysis, 10 banks have been found to be $100 \%$ efficient. This finding shows that 10 banks are technically efficient. The average efficiency score of these banks has been found as 0.100 .

Likewise, in the SDFI radial output oriented analysis, 10 banks have been found to be $100 \%$ efficient, as well. This finding shows that 10 banks are technically efficient. The average efficiency score of these banks has been found to be equal to be 1.00 (Table 2).

It seems at SDFI-output and SDFI-input efficiency scores (Table 2) that the 10 banks are efficient with respect to the two measurements. 
Table 2

Scale Dependent Fixed Income (SDFI) Radial Input/Output Oriented DEA Scores for the Year 2010

\begin{tabular}{llll}
\hline Number & Decision units & SDFI radial input oriented & SDFI radial output oriented \\
\hline 1 & ISBANK & $100.00 \%$ & $100.00 \%$ \\
2 & AKBANK & $100.00 \%$ & $100.00 \%$ \\
3 & YAPI KREDI BANK & $100.00 \%$ & $100.00 \%$ \\
4 & GARANTI BANK & $100.00 \%$ & $100.00 \%$ \\
5 & HALKBANK & $100.00 \%$ & $100.00 \%$ \\
6 & VAKIFBANK & $100.00 \%$ & $100.00 \%$ \\
7 & TURKISH ECONOMY BANK (TEB) & $100.00 \%$ & $100.00 \%$ \\
8 & FINANSBANK & $100.00 \%$ & $100.00 \%$ \\
9 & DENIZBANK & $100.00 \%$ & $100.00 \%$ \\
10 & BANKASYA & $100.00 \%$ & $100.00 \%$ \\
\hline
\end{tabular}

Table 3

Scale Dependent Fixed Income (SDFI) Radial Input and Output Oriented Super Efficiency Scores Brand Value Rankings

\begin{tabular}{lllcc}
\hline Decision units & $\begin{array}{l}\text { SDFI radial input } \\
\text { oriented }\end{array}$ & $\begin{array}{l}\text { SDFI radial output } \\
\text { oriented }\end{array}$ & $\begin{array}{l}\text { Super efficiency score } \\
\text { ranking }\end{array}$ & Brand value ranking \\
\hline ISBANK & $104.09 \%$ & $96.07 \%$ & 9 & 1 \\
AKBANK & $106.80 \%$ & $93.63 \%$ & 8 & 2 \\
YAPI KREDI BANK & $129.40 \%$ & $77.28 \%$ & 3 & 3 \\
GARANTI BANK & $108.27 \%$ & $92.36 \%$ & 7 & 4 \\
HALKBANK & $122.10 \%$ & $81.90 \%$ & 4 & 5 \\
VAKIFBANK & $100.91 \%$ & $99.10 \%$ & 10 & 6 \\
TEB & $172.89 \%$ & $57.84 \%$ & 1 & 7 \\
FINANSBANK & $108.95 \%$ & $91.78 \%$ & 6 & 8 \\
DENIZBANK & $119.06 \%$ & $83.99 \%$ & 5 & 9 \\
BANKASYA & $135.63 \%$ & $73.73 \%$ & 2 & 10 \\
\hline
\end{tabular}

In order to make a ranking in itself of the banks that turned out to be fully efficient with 2010 data, super efficiency ranking has been calculated (Table 3). In the measurement of SDFI radial input oriented super efficiency, the observer looks at the extent of divergence (increase) from 100. However, in the measurement of SDFI radial output oriented super efficiency measurement, the observer looks at the extent of approximation to zero. It appears at the input and output oriented super efficiency ranking that Turkish Economy Bank (TEB), Bankasya, and Yapi Kredi Bank are the first three, respectively. Looking at the brand values of the same banks, TEB ranks 7th, Bankasya ranks 10th, and Yapi Kredi Bank ranks third.

In the SDFI radial input oriented analysis (Table 4), nine banks have been found to have $81 \%$ efficiency. This finding shows that nine banks are technically efficient. Average efficiency score of these banks has been determined to be 0.81 .

When the firms are assessed individually, among the banks determined to be inefficient with respect to SDFI model, it is seen that Sekerbank has the lowest efficiency score (0.85) and TEB has the highest (0.95) efficiency score. This situation shows that the firm with $85 \%$ efficiency score works with $15 \%$ idle capacity and the firm with $95 \%$ efficiency score works with $5 \%$ idle capacity. Therefore, Sekerbank is the weakest bank 
from the perspective of technical efficiency. If this bank increases its capacity 1.17 times, its efficiency score will be equal to 1 .

In the SDFI radial output oriented analysis, nine banks have been found to be $81 \%$ efficient. This finding shows that nine banks are technically efficient.

It seems at SDFI-output and SDFI-input scores (Table 4) that nine banks are efficient with respect to both measurements. By confirming the scores of other two banks, reciprocally their inefficiency levels are observed, for example, the bank with SDFI-input level 0.85 has SDFI-output level of 1.17. This means that in order for this bank which has been working with 0.17 idle capacity to become efficient, it should perform 0.17 rate higher after attaining its current efficiency score (after its efficiency rate becomes 1).

\section{Table 4}

Scale Dependent Fixed Income (SDFI) Radial Input/Output Oriented DEA Scores for the Year 2010

\begin{tabular}{llll}
\hline Number & Decision units & SDFI radial input oriented & SDFI radial output oriented \\
\hline 1 & ISBANK & $100 \%$ & $100 \%$ \\
2 & AKBANK & $100 \%$ & $100 \%$ \\
3 & GARANTI BANK & $100 \%$ & $100 \%$ \\
4 & YAPI KREDI BANK & $100 \%$ & $100 \%$ \\
5 & VAKIFBANK & $100 \%$ & $100 \%$ \\
6 & HALKBANK & $100 \%$ & $100 \%$ \\
7 & FINANSBANK & $100 \%$ & $100 \%$ \\
8 & TEB & $95.04 \%$ & $105.22 \%$ \\
9 & DENIZBANK & $100 \%$ & $100 \%$ \\
10 & BANKASYA & $100 \%$ & $100 \%$ \\
11 & SEKERBANK & $85.05 \%$ & $117.58 \%$ \\
\hline
\end{tabular}

In the measurement of SDFI radial input-output oriented super efficiency for the year 2011 (Table 5), Denizbank, Bank Asya, and Garanti Bank have taken the first three places, respectively. When brand values of these same banks are taken into account, it is seen that Denizbank ranks 9th, Bank Asya ranks 10th, and Garanti Bank ranks third. Additionally, Vakifbank's efficiency ranking is 4 while its brand value ranking is 5, Halkbank's efficiency ranking is 5 while its brand value ranking is 6 , and Finansbank's efficiency 6 while its brand value is seventh. Only Garanti Bank and Sekerbank have the same efficiency rankings as their brand value rankings are $18 \%$. When the year 2011 is assessed, although one cannot observe a parallelism between efficiency rankings of the banks and their brand value rankings, it is seen that for many of the banks, closer values have been attained.

In the SDFI radial input oriented analysis, eight banks have been found to be efficient (with $100 \%$ score). This finding shows that 10 banks are technically efficient. Average efficiency score of these banks has been determined as 0.10 .

In the SDFI radial output oriented analysis, again eight banks (100\%) have been found to be efficient. This finding shows that 10 banks are technically efficient. Average efficiency score of these firms has been determined as 1.00 (Table 6).

It appears at the SDFI-output and SDFI-input scores (Table 6) that 10 banks seem to be efficient with respect to the both measurements. 
Table 5

Year 2011 Brand Value Rankings of Scale Dependent Fixed Income (SDFI) Radial Input and Output Oriented Super Efficiency Scores

\begin{tabular}{|c|c|c|c|c|}
\hline Decision units & $\begin{array}{l}\text { SDFI radial input } \\
\text { oriented }\end{array}$ & $\begin{array}{l}\text { SDFI radial output } \\
\text { oriented }\end{array}$ & $\begin{array}{l}\text { Super efficiency score } \\
\text { ranking }\end{array}$ & Brand value ranking \\
\hline ISBANK & $102.14 \%$ & $97.91 \%$ & 9 & 1 \\
\hline AKBANK & $108.07 \%$ & $92.54 \%$ & 7 & 2 \\
\hline GARANTI BANK & $123.68 \%$ & $80.85 \%$ & 3 & 3 \\
\hline YAPI KREDI BANK & $102.86 \%$ & $97.22 \%$ & 8 & 4 \\
\hline VAKIFBANK & $122.55 \%$ & $81.60 \%$ & 4 & 5 \\
\hline HALKBANK & $119.58 \%$ & $83.62 \%$ & 5 & 6 \\
\hline FINANSBANK & $111.93 \%$ & $89.34 \%$ & 6 & 7 \\
\hline TEB & $95.04 \%$ & $105.22 \%$ & 10 & 8 \\
\hline DENIZBANK & $146.86 \%$ & $68.09 \%$ & 1 & 9 \\
\hline BANKASYA & $124.20 \%$ & $80.51 \%$ & 2 & 10 \\
\hline SEKERBANK & $85.05 \%$ & $117.5 \% 8$ & 11 & 11 \\
\hline
\end{tabular}

Table 6

Scale Dependent Fixed Income (SDFI) Radial Input/Output Oriented DEA Scores for the Year 2012

\begin{tabular}{llll}
\hline Number & Decision units & SDFI radial input oriented & SDFI radial output oriented \\
\hline 1 & AKBANK & $100 \%$ & $100 \%$ \\
2 & ISBANK & $100 \%$ & $100 \%$ \\
3 & GARANTI BANK & $100 \%$ & $100 \%$ \\
4 & YAPI KREDI BANK & $100 \%$ & $100 \%$ \\
5 & HALKBANK & $100 \%$ & $100 \%$ \\
6 & VAKIFBANK & $100 \%$ & $100 \%$ \\
7 & FINANSBANK & $100 \%$ & $100 \%$ \\
8 & DENIZBANK & $100 \%$ & $100 \%$ \\
\hline
\end{tabular}

\section{Table 7}

Year 2012 Brand Value Rankings of Scale Dependent Fixed Income (SDFI) Radial Input and Output Oriented Super Efficiency Scores

\begin{tabular}{lllll}
\hline Decision units & $\begin{array}{l}\text { SDFI radial input } \\
\text { oriented }\end{array}$ & $\begin{array}{l}\text { SDFI radial output } \\
\text { oriented }\end{array}$ & $\begin{array}{l}\text { Super efficiency score } \\
\text { ranking }\end{array}$ & Brand value ranking \\
\hline AKBANK & $107.84 \%$ & $92.73 \%$ & 6 & 1 \\
ISBANK & $119.79 \%$ & $91.23 \%$ & 2 & 2 \\
GARANTI BANK & $107.94 \%$ & $92.65 \%$ & 5 & 3 \\
YAPI KREDI BANK & $105.43 \%$ & $94.85 \%$ & 7 & 4 \\
HALKBANK & $122.34 \%$ & $81.74 \%$ & 1 & 5 \\
VAKIFBANK & $116.34 \%$ & $85.95 \%$ & 3 & 6 \\
FINANSBANK & $116.29 \%$ & $85.99 \%$ & 4 & 7 \\
DENIZBANK & $103.72 \%$ & $96.41 \%$ & 8 & 8 \\
\hline
\end{tabular}

In SDFI radial input-output oriented super efficiency measurement for year 2012 (Table 7), Halkbank, Isbank, and Vakifbank have shared the first three places, respectively. The brand values of the same banks rank fifth, second, and sixth, respectively. Denizbank's efficiency score ranking and brand value ranking is eighth in 
each. When the year 2012 is assessed, only İşbank's and Sekerbank's (at the rate of 25\%) efficiency and brand value rankings are the same.

\section{Conclusions}

In this study, efficiencies of the banks, brand values of which were calculated by Brand Finance, a brand valuation institution, with their own proprietary method and which take a place in Global Banking 500 list with a brand value ranking, and which trade in Istanbul Stock Exchange, have been measured with DEA method. The resulting efficiency ranking has been compared with brand value ranking of the banks. The input and output variables subject to DEA analysis have been obtained from 2010 to 2012 balance sheets and income statements of DMU published on KAP. For the DEA, three inputs and four outputs have been used.

When the results of this study are evaluated, it is observed that 10 banks subject to the study were efficient $(100 \%)$ in 2010. In order to make ranking within the banks that turn out to be fully efficient, their super efficiency scores have been calculated. It comes in view at the input and output oriented super efficiency ranking that TEB, Bank Asya and Yapi Kredi Bank share the first three places, respectively. When the brand values are assessed, however, İşbank, Akbank, and Yapi Kredi Bank share the top three posts. From the perspective of brand value and efficiency ranking, a relation in the amount of $10 \%$ has been observed for 2010 . Only Yapi Kredi Bank has taken the third place in both brand value and efficiency rankings.

In 2011, however, efficiency of the banks has turned out to be $81 \%$ and two of the 11 banks have been found to be relatively inefficient than the others. Looking at the super efficiency scores for 2011 Denizbank, Bank Asya and Garanti Bank have shared the first three places. When the brand value ranking is assessed however, İşbank, Akbank, and Garanti Bank have shared the top three places. From the perspective of brand value and efficiency value ranking, a relation in the amount of $18 \%$ has been observed for 2011. Garanti Bank has taken the third place and Sekerbank has taken the 11th place in both brand value and efficiency rankings.

In 2012, efficiency of the banks has been 100\% and Halkbank, İşbank, and Vakifbank have shared the top three places, respectively from the super efficiency perspective. The top three places from the perspective of brand value however, have been shared by Akbank, İşbank, and Garanti Bank, respectively. From the perspective of brand value and efficiency value ranking, a relation in the amount of $25 \%$ has been observed for 2012. İşbank has taken the second place and Denizbank has taken the 8th place in both brand value and efficiency rankings.

Looking at the correspondence numbers (or rates), it can be said that they are not on a par with the expectation. At least a relation of $50 \%$ could allow making new positive comments about this sector. With these available outcomes, it can be said that efficiency of the banks and brand values do not match with each other in the rate of $90 \%$.

In this study, it cannot be talked about a relation between brand value and super efficiency scores. Likewise, the fact that Turkish Economy Bank has efficiency ranking of 1 but brand value ranking of 7 in 2010, Denizbank has efficiency ranking of 1 but brand value ranking of 9 in 2011, and Halkbank has efficiency ranking of 1 but brand value ranking of 5 in 2012 is noteworthy. Similarly, the fact that Isşbank has brand value ranking of 1 but efficiency ranking of 9 in 2010, again İşbank has brand value ranking of 1 but efficiency ranking of 9 in 2011, and Akbank has brand value ranking of 1 but efficiency ranking of 6 is an attention grabbing point. Within this context, the fact that in the study, brand value and super efficiency rankings do not match with each other makes to think that more elaborate studies in this field should be conducted in the future. 
When the points constituting sensitive core of the study are assessed as a whole, it can be said that when DEA results are assessed, the point one should take into account is that the results show relative efficiency values. Here, a bank's being $100 \%$ efficient only means that this particular bank is $100 \%$ efficient with respect to other banks and within the framework of predefined inputs and outputs.

Another sensitivity of the study is that different input and output variables are used in using DEA method for efficiency determination. When the fact that these variables can change efficiency results of firms is taken into consideration, it is imperative to pick up input and output variables from the best available input/outputs sets representing that particular sector. Likewise, another constraint that has an impact on determination of number of inputs/outputs is that number of banks that are listed in Global Banking 500 and brand value of which are calculated and ranked was 10 in 2010, 11 in 2011, and eight in 2012.

\section{References}

Aydin, G., \& Uluengin, B. (2011). Impact of consumer based brand value on financial performance. Journal of Istanbul Technical University/d engineering, 10(2), 58-68.

Bakirci, F. (2006). Effectiveness and efficiency measurement in production data envelopment analysis theory and application. İstanbul: Atlas Publications.

Bayıksel, Ş. Ö. (2007). Türkiye'nin En Değerli Markaları (Turkey's most valuable brands). Retrieved from $\mathrm{http} / / / w w w . c a p i t a l . c o m . t r / c a p i t a l-d e r g i /$ turkiyenin-en-degerli-markalari-haberdetay-4573 adresinden alınd 1

Celik, A. E. (2013). Brand valuation. Journal of Accounting and Finance, 60, 195-208.

Charnes, A., Cooper, W. W., \& Rhodes, E. J. (1978). Measuring the efficiency of decision making units. European Journal of Operational Research, 2, 429-444.

Çilingir, A. İ. (2009). Marka Değeri Nedir (What is the brand value)? Retrieved from http://www.markadegeri.com/icerik.asp?id=875 adresinden alınd 1

Farrel, M. J. (1957). The measurement of productive efficiency. Journal of Royal Statistical Society, 120(3), 253-290.

Firat, D., \& Badem, C. (2008). Brand valuation methods and reflecting brand value on financial tables. Journal of Accounting and Finance, 38, 210-219.

Gülcü, A. (2001). Relative efficiency analysis on Cumhuriyet University research hospital using data envelopment analysis. Journal of Productivity, 4, 113-138.

Ilguner, M. (2009). Brand value; single most important indicator of success. Journal Cerceve, 17(52), 168-173.

Karsak, E., \& Iscan, E. F. (2000). Assessment of relative activity performances in cement sector through data envelopment analysis by using weight limits and cross efficiency. Journal of Industrial Engineering, 11(3), 2-3.

Kaya, Y. (2005). Brand valuation methods and effects of taking brands into financial tables (Unpublished master's thesis, Marmara University, Institute of Banking and Insurance Capital Markets and Stock Exchange).

Kuosmanen, T. (2003). Modeling blank data entries in data envelopment analysis (Econ-WPA working paper at WUSTL, (0210001)).

Marangoz, M. (2007). Research on measuring brand value based on consumer behavior. Marmara University Journal of Social Sciences Institute, 7(28), 87-96.

Ozguven, N. (2010). Brand value: Assessment of global brands. Journal of Organization and Management Sciences, 2(1), 141-148.

Tek, O. B., \& Ozgul, E. (2005). Modern marketing principles applied managerial approach. Izmir: Birlesik Publications.

Ulucan, A. (2000). Data envelopment analysis approach in measuring company performances: General and sector based assessments. Journal of Hacettepe University Economics and Administrative Sciences, 18, 405-418.

Ulucan, A. (2002). Data envelopment analysis approach in measuring efficiencies of ISO 500 companies' assessments with different input output components and scale dependent income approaches Ankara University. Journal of Faculty of Political Sciences, 57(2), 185-202.

Yilmaz, B., \& Guzel, T. (2012). Brand valuation and its importance: An analysis with relief from royalty method. Journal of Accounting and Finance, 54, 141-156. 